\title{
A new decade, a new seasonal influenza: the Council of the European Union Recommendation on seasonal influenza vaccination
}

A Nicoll (angus.nicoll@ecdc.europa.eu) ${ }^{1}$

1. European Centre for Disease Prevention and Control, Stockholm, Sweden

Citation style for this article:

Citation style for this article: Nicoll A. A new decade, a new seasonal influenza: the Council of the European Union Recommendation on seasonal influenza vaccination. Euro Surveill. 2010;15(1):pii=19458. Available online: http://www.eurosurveillance.org/ViewArticle.aspx?Articleld=19458

This article has been published on 7 January 2010

Europe is coming to the end of its autumn-winter wave of the 2009 influenza $A\left(\mathrm{H}_{1} \mathrm{~N}_{1}\right)$ pandemic. Transmission has been continuing in the east and south-east of Europe, but the signs from other parts of Europe before Christmas indicated that the circulation of the pandemic influenza $A\left(\mathrm{H}_{1} \mathrm{~N}_{1}\right)$ virus was declining. Though as is to be expected the associated burden on hospitals and especially on intensive care, and the number of deaths are declining less quickly and with some delay $[1,2]$. Worldwide in almost all countries with virological surveillance pandemic viruses are pre-dominating apart from co-circulating influenza $B$ viruses [3]. In Europe, there have hardly been any influenza $\left(\mathrm{AH}_{3}\right)$ viruses in this season so far, and even fewer of the previous seasonal influenza $A\left(\mathrm{H}_{1}\right)$ viruses [1].

So what happens next and what needs to be done? The historical pattern of human influenzas is that after pandemics, the world experiences a new mix of viruses referred to as inter-pandemic influenza or as seasonal influenza in temperate countries. In the three 2oth-century pandemics, the new pandemic virus displaced the previous influenza A seasonal viruses, with a variation for the last three decades due to the re-emergence of an $\mathrm{A}\left(\mathrm{H}_{1} \mathrm{~N}_{1}\right)$ virus (Figure) [4]. Hence, what now has to be done is to determine the characteristics of the coming, new seasonal influenza based first on the growing knowledge of the 2009 pandemic influenza, then on the experiences from the coming influenza season first in the southern hemisphere and then in Europe. These characteristics should then be compared to those of the previous seasonal influenza to be able to determine a rational approach to mitigation, treatment and vaccination [5].

The 2009 pandemic influenza has some similarities with the previous seasonal influenza but there are also a number of important differences. The incidence of severe disease in children and pregnant women from 2009 pandemic influenza seems to be higher than from the previous seasonal influenza. Furthermore, there is residual immunity in many older people, though older people who were not immune had the highest mortality rate of any age group in this pandemic. Another uncommon but striking feature was the prominence of sudden acute illness and deaths due to acute respiratory disease syndrome (ARDS) [5,6]. ARDS had been seen before in association with seasonal influenza, but was even more uncommon. If the features described persist with the new seasonal influenza, this may have an impact on the details of recommendations for seasonal influenza immunisation. To gather the scientific evidence, Europe will need to additionally focus its surveillance on severe cases, so called severe acute respiratory infections (SARI), and especially deaths [7]. Such surveillance has started in the pandemic under a strategy agreed with the European Union Member States, but it now needs to be extended to more countries and to capture more data on deaths [1, 7-9].

Influenza A never stands still. What is true at the moment for the 2009 influenza $A\left(\mathrm{H}_{1} \mathrm{~N}_{1}\right)$ will probably not remain so. The virus responsible for the last pandemic in 1968-70 became more transmissible between its first and second winter so that there were more cases and deaths in 1969-70 in at least two European countries $[10,11]$. The $1957-8$ pandemic, declined before Christmas, but then saw a rise in the new year in influenza-related deaths, though not in cases $[12,13]$. Serological data such as that already gathered by France and the United Kingdom and close epidemiological and virological surveillance throughout the year are essential to determine how likely these scenarios will be in 2010-11 [14,15]. In 2007-8, the seasonal influenza $\mathrm{A}\left(\mathrm{H}_{1} \mathrm{~N}_{1}\right)$ virus suddenly became resistant to the main oral antiviral oseltamivir, a change that seemingly was not related to the use of antivirals $[16,17]$. The rule with influenza, pandemic and inter-pandemic, is to maintain vigilance and expect the unexpected.

The most potent countermeasure for any human influenza is vaccination. With prescience the Member States of the European Union (EU) collectively as the Council of the European Union have just adopted under the Swedish Presidency a formal recommendation promoting seasonal influenza vaccination [18]. 
This has a number of important features (Box), puts responsibilities to Member States to enact vaccination programmes and to monitor coverage. The European Centre for Disease Prevention and Control (ECDC) is to provide technical support from its Seasonal Influenza Immunisation Programme including its work with the Vaccine European New Integrated Collaboration Effort (VENICE) project to monitor policies, practices and coverage. Much is to be done, as uptake in the older age groups varies forty-fold between Member States, some countries cannot provide data at all, and most find it difficult to monitor coverage in the clinical risk groups [19]. A group especially singled out for attention and immunisation by the European Council are healthcare workers (HCW). An article in this week's issue by $M$. Chironna et al. illustrates the necessity for HCW to get vaccinated against influenza [20]. Highly vulnerable patients, hospitalised children with cancer, were probably infected by unimmunised healthcare staff. A number of HCW in Europe choose not to be vaccinated. While the reasons for this may be manifold, what needs to be emphasised with them is that this is not just for their own protection. The most important reason for them to get immunised is to protect their vulnerable patients who often belong to risk groups for influenza.

The question of whether there are also other groups who would benefit from seasonal influenza vaccination, such as young children who have not been exposed to the 2009 pandemic influenza and pregnant women, can only be answered by close European and global epidemiological and virological surveillance in the months to come $[7,8]$. Results from such common efforts will provide guidance for EU Member States in their decisions for whom to recommend the seasonal influenza vaccine in the autumn of 2010.

\section{References}

1. European Centre for Disease Prevention and Control. Weekly Influenza Surveillance Overview. Stockholm: ECDC; January 2010. Available from: http://ecdc.europa.eu/en/activities/ surveillance/EISN/Pages/EISN_Bulletin.aspx

2. Health Protection Agency. HPA Weekly National Influenza report. London: HPA;31 December 2009. Available from: http:// www.hpa.org.uk/web/HPAwebFile/HPAweb_C/1259152455206

3. Centers for Disease Control and Prevention. $2009 \mathrm{H}_{1} \mathrm{~N}_{1}$ Flu: International Situation Update. Atlanta:CDC; 4 January 2010. Available from: http://www.cdc.gov/h1n1flu/updates/ international/

4. Kilbourne ED. Influenza pandemics of the 2oth century. Emerg Infect Dis. 2006;12(1):9-14.

5. European Centre for Disease Prevention and Control. ECDC Risk Assessment. 2009 influenza $A\left(\mathrm{H}_{1} \mathrm{~N}_{1}\right)$ pandemic. Version 7. Stockholm: ECDC; 17 December 2009. Available from: http:// ecdc.europa.eu/en/healthtopics/Documents/0908_Influenza_ AH1N1_Risk_Assessment.pdf

6. Jain S, Kamimoto L, Bramley AM, Schmitz AM, Benoit SR, Louie J, et al Hospitalized Patients with $2009 \mathrm{H}_{1} \mathrm{~N}_{1}$ influenza in the United States, April-June 2009. N Engl J Med. 2009;361(20):1935-44.

7. World Health Organisation. Human infection with pandemic $\left(\mathrm{H}_{1} \mathrm{~N}_{1}\right) 2009$ virus: updated interim WHO guidance on global surveillance. Geneva: WHO; 10 July 2009. Available from: http://www.who.int/csr/resources/publications/swineflu/ interim_guidance/en/index.html
8. European Centre for Disease Prevention and Control. Overview of surveillance of influenza 2009/2010 in the EU/EEA. Stockholm: ECDC; September 2009 Available from: http:// www.ecdc.europa.eu/en/publications/Publications/0909_TED_ Overview_of_Surveillance_of_Influenza_2009-2010_in_EUEEA.pdf

9. European Centre for Disease Prevention and Control. Surveillance of communicable diseases in the European Union, a long-term strategy: 2008-2013. Stockholm: ECDC; 2008. Available from: http://www.ecdc.europa.eu/documents/pdf/ Surveillance_of_CD_EU.pdf

10. Jackson C, Vynnycky E, Mangtani P. Estimates of the transmissibility of the 1968 (Hong Kong) influenza pandemic: evidence of increased transmissibility between successive waves. Am J Epidemiol. 10 December 2009. doi:10.1093/aje/ kwp394.

11. Rizzo C, Bella A, Viboud C, Simonsen L, Miller MA, Rota MC, et al. Trends for influenza-related deaths during pandemic and epidemic seasons, Italy, 1969-2001. Emerg Infect Dis. 2007;13(5):694-9

12. Henderson DA Courtney B, Inglesby TV, Toner E, Nuzzo JB. Public Health and Medical Responses to the 1957-58 Influenza Pandemic. Biosecur Bioterror. 2009;7(3):265-73.

13. Dauer CC. Mortality in the $1957-8$ influenza pandemic. Public Health Reports. 1958;73(9):803-810.

14. Institut de Veille Sanitaire. Bulletin Grippe $A\left(\mathrm{H}_{1} \mathrm{~N}_{1}\right) 2009$ No. 75. [Influenza $A\left(\mathrm{H}_{1} \mathrm{~N}_{1}\right) 2009$ bulletin No. 75]. Point de situation au 15 décembre 2009. SéroGrippeHebdo seroprévalence du virus $A\left(\mathrm{H}_{1} \mathrm{~N}_{1}\right) 2009$ chez les femmes enceintes. [Situation report of 15 December 2009. Seroprevalence of the $A\left(\mathrm{H}_{1} \mathrm{~N}_{1}\right)$ 2009 virus in pregnant women]. Paris:InVs; 2009 . French. Available from: http://www.invs.sante.fr/surveillance/ grippe_dossier/points h1n1/grippe_A h1n1_151209/Bulletin grippe_15_12_09.pdf\#page=2

15. Health Protection Agency. Pandemic ( $\left.\mathrm{H}_{1} \mathrm{~N}_{1}\right) 2009$ in England: an overview of initial epidemiological findings and implications for the second wave. Version 4. London: HPA; 2 December 2009. Available from: http://www.hpa.org.uk/web/ HPAwebFile/HPAweb C/1258560552857

16. Meijer A, Lackenby A, Hungnes 0 , Lina B, van der Werf $\mathrm{S}$, Schweiger $\mathrm{B}$, et al. Oseltamivir-resistant influenza $\mathrm{A}$ (H1N1) virus, Europe, 2007-08 season. Emerg Infect Dis. 2009;15(4):552-60.

17. Kramarz P, Monnet D, Nicoll A, Yilmaz C, Ciancio B. Use of oseltamivir in 12 European countries between 2002 and 2007 lack of association with the appearance of oseltamivir-resistant influenza $A\left(\mathrm{H}_{1} \mathrm{~N}_{1}\right)$ viruses. Euro Surveill. 2009;14(5):pii=19112. Available from: http://www.eurosurveillance.org/ViewArticle. aspx?Articleld $=19112$

18. Council of the European Union. Council Recommendation of 22 December 2009 on seasonal influenza vaccination (Text with EEA relevance)(2009/1019/EU). Official Journal of the European Union. 2009. L 348/71. Available from: http://eur-lex.europa. eu/LexUriServ/LexUriServ.do?uri=0J:L:2009:348:0071:0072:E $\mathrm{N}: \mathrm{PDF}$

19. Mereckiene J, Cotter S, Nicoll A, Lévy-Bruhl D, Ferro A, Tridente G, et al. National Seasonal Influenza Vaccination Survey in Europe, 2008. Euro Surveill. 2008;13(43): pii=19017. Available from: http://www.eurosurveillance.org/ViewArticle. aspx?Articleld $=19017$

20. Chironna M, Germinario CA, Tafuri S, Santoro N, Prato R, Quarto M. A nosocomial outbreak of 2009 pandemic influenza $A\left(\mathrm{H}_{1} \mathrm{~N}_{1}\right)$ in a paediatric oncology ward in Italy, October - November 2009. Euro Surveill. 2010;15(1): pii=19454. Available from: http://www.eurosurveillance.org/ViewArticle. aspx?Articleld $=19454$ 